\title{
Spatial Features of Exhibition Grounds in the Czech Republic
}

\section{Prostorové kvality výstavních areálů v České republice}

Lenka Štěpánková

Ústav urbanismu, Fakulta architektury, Vysoké učení technické v Brně školitel: doc. Ing. arch. Maxmilián Wittmann, Ph.D.

\begin{abstract}
The five most important exhibition grounds in the Czech Republic were analysed to discover how their spatial layouts are related to the type of the venue and its connection to the city. Apart from the function and space structure, the historical development, legal status and ownership as well as planning issues were taken into account as they can help to explain specific traits of some of the exhibition grounds and obvious differences between them. During the process emphasis was on the use of open source data so the analysis can be repeated in future with the results being either verified or refined, and so the research can possibly be extended to exhibition grounds in other European cities.
\end{abstract}

KEYWORDS: fairs; urban research; spatial analysis; exhibition grounds; Czech Republic

\begin{abstract}
ABSTRAKT: Průzkum provedený u pěti nejvýznamnějších výstavních areálů v České republice mapuje jejich prostorovou strukturu, způsob zapojení do urbánní struktury a charakter hranic. Zjištěné charakteristiky, jako je využitelnost a míra zastavěnosti, dává do souvislostí s jejich převažující funkční náplní a historickým vývojem. Porovnáváno je také vlastnictví a status území v územněplánovací dokumentaci. Jako vstupní informace jsou v maximální možné míře využívána volně dostupná otevřená data, aby bylo možné výsledky využít také k porovnání s výstavními a veletržními areály $\mathrm{v}$ dalších evropských městech.
\end{abstract}

KLÍČOVÁ SLOVA: veletržní areály; výstaviště; Česká republika; prostorové charakteristiky 


\section{$54 \quad$ PReS 2018 conference papers}

\section{Úvod}

Výběr výstavních a veletržních areálů pro výzkum byl proveden na základě oborových statistik[1]. Kritériem přitom byla velikost areálu a význam v něm pořádaných akcí (mezinárodní veletrhy a celonárodní přehlídky). Nejvýznamnější výstaviště v České republice $\mathrm{z}$ tohoto pohledu představují areály v Brně, Českých Budějovicích, Olomouci a v pražských Letňanech. Pro srovnání byl do výběru zařazen také výstavní areál v pražských Holešovicích, který je zajímavý vzhledem ke své historii a dlouhé kontinuální existenci v dané lokalitě[2].

\begin{tabular}{|c|c|c|c|c|c|}
\hline & Brno & České Budějovice & Olomouc & Praha-Holešovice & Praha-Letňany \\
\hline název areálu & Výstaviště Brno, BVV & $\begin{array}{l}\text { Výstaviště České } \\
\text { Budějovice }\end{array}$ & Výstaviště Flora Olomouc & Výstaviště Praha & PVA EXPO Praha \\
\hline vznik areálu & \begin{tabular}{|l|}
1928 - Výstava soudobé \\
kultury v \\
Československu
\end{tabular} & $\begin{array}{l}\text { 60. léta 20. století, od } 70 . \\
\text { let zemědělská výstava } \\
\text { Země živitelka }\end{array}$ & $\begin{array}{l}\text { 50. léta 20. století, od } 60 . \\
\text { let mezinárodní výstava } \\
\text { Flora Olomouc }\end{array}$ & $\begin{array}{l}1891 \text { - Všeobecká zemská } \\
\text { jubilejní výstava }\end{array}$ & po r. 2000 \\
\hline $\begin{array}{r}\text { celková rozloha } \\
\text { (podle } \\
\text { mapových } \\
\text { podkladů) }\end{array}$ & 61 ha & 24 ha & 44 ha (při akci až 23 ha) & 24 ha & 9 ha \\
\hline portfolio akcí & \begin{tabular}{|l|} 
veletrhy, kongresy, \\
odborné konference, \\
výstavy, koncerty a \\
kulturní akce, sportovní \\
akce, firemní eventy \\
\end{tabular} & $\begin{array}{l}\text { celonárodní zemědělská } \\
\text { výstava, veletrhy a } \\
\text { výstavy, společenské a } \\
\text { kulturní akce, sportovní } \\
\text { aktivity }\end{array}$ & \begin{tabular}{|l|} 
celonárodní zahradnická \\
výstava, kulturní a \\
společenské akce a \\
výstavy, stálé expozice \\
(sbírkové skleníky a \\
parky)
\end{tabular} & $\begin{array}{l}\text { výstavy, koncerty, divadlo a } \\
\text { kino, festivaly, rodinné } \\
\text { akce, sport, volnočasové } \\
\text { aktivity }\end{array}$ & $\begin{array}{l}\text { veletrhy, výstavy, } \\
\text { koncerty, festivaly, } \\
\text { firemní eventy, kongresy } \\
\text { a společenské akce }\end{array}$ \\
\hline $\begin{array}{r}\text { provozovatel } \\
\text { areálu }\end{array}$ & Veletrhy Brno, a.s. & \begin{tabular}{|l} 
Výstaviště České \\
Budějovice a.s.
\end{tabular} & $\begin{array}{l}\text { Výstaviště Flora } \\
\text { Olomouc, a.s. }\end{array}$ & $\begin{array}{l}\text { Výstaviště Praha, a.s. (do r. } \\
2016 \text { INCHEBA EXPO PRAHA } \\
\text { spol s. r.o.) }\end{array}$ & ABF, a.s. \\
\hline právníforma & akciová společnost & akciová společnost & akciová společnost & \begin{tabular}{|l|l} 
akciová společnost & a \\
\end{tabular} & akciová společnost \\
\hline $\begin{array}{r}\text { vlastník } \\
\text { společnosti }\end{array}$ & Statutární město Brno & \begin{tabular}{|l|} 
Podpůrný a garanční \\
rolnický a lesnický fond, \\
a.s.; vlastníkem PGRLF je \\
Česká republika, práva \\
akcionáře zajištuje \\
Ministerstvo zemědělství
\end{tabular} & $\begin{array}{l}\text { Statutární město } \\
\text { Olomouc }\end{array}$ & Hlavní město Praha & $\begin{array}{l}\text { soukromý majitel } \\
\text { podrobnosti viz } \\
\text { poznámka }\end{array}$ \\
\hline $\begin{array}{r}\text { vlastník } \\
\text { pozemků }\end{array}$ & Veletrhy Brno, a.s. & $\begin{array}{l}\text { Výstaviště České } \\
\text { Budějovice a.s. }\end{array}$ & $\begin{array}{l}\text { Výstaviště Flora } \\
\text { Olomouc, a.s. + } \\
\text { Statutární město } \\
\text { Olomouc (= plochy } \\
\text { městských sadů) }\end{array}$ & Hlavní město Praha & $\begin{array}{l}\text { Výzkumný a zkušební } \\
\text { letecký ústav, a.s. }\end{array}$ \\
\hline $\begin{array}{r}\text { status areálu v } \\
\text { ÚPD (podle } \\
\text { Hlavního } \\
\text { výkresu } \\
\text { príslušného ÚP) }\end{array}$ & $\begin{array}{l}\text { ostatní zvláštní plocha } \\
\text { (rozdělení na plochu } \\
\text { stabilizovanou a } \\
\text { návrhovou) }\end{array}$ & $\begin{array}{l}\text { smiššné území s } \\
\text { bydlením kolektivního } \\
\text { charakteru, s vy̌̌ší až } \\
\text { nejvyšší mírou městské } \\
\text { regulace }\end{array}$ & \begin{tabular}{|l|} 
plochy veřejného \\
vybavení, plochy veřejné \\
rekreace (= plochy \\
městských sadů)
\end{tabular} & $\begin{array}{l}\text { plochy pro kulturní a } \\
\text { církevní zařizení }\end{array}$ & $\begin{array}{l}\text { plochy všeobecně } \\
\text { smišené, částečně } \\
\text { plochy pro nerušící } \\
\text { výrobu a služby }\end{array}$ \\
\hline $\begin{array}{r}\text { aktuální rozvoj, } \\
\text { plány }\end{array}$ & \begin{tabular}{|l|} 
mezinárodní \\
urbanistická ideová \\
soutě̌̌ 2017, rozvojový \\
plán výstaviště \\
masterplan 2017, v \\
př́pravě územní studie \\
a nový ÚP města Brna \\
(KAM Brno), plán \\
výstavby nového \\
pavilonu Da \\
rekonstrukce pavilonu C
\end{tabular} & \begin{tabular}{|l|} 
výzva 2017-2020 \\
modernizace areálu, \\
areál jako volnočasový \\
park; př́iprava \\
rekonstrukce pavilonu D8 \\
(výroční zpráva 2016) \\
\\
\end{tabular} & \begin{tabular}{|l} 
od r. 2012 probíhající \\
celková obnova areálu \\
jako ukázky zahradní a \\
krajinářské architektury, \\
v r. 2014 rekonstrukce \\
pavilonu A, územní \\
studie 2018 (arch. \\
Zdeněk Sendler), záměr \\
výstavby nového \\
pavilonu B
\end{tabular} & $\begin{array}{l}\text { koncepce budoucího využití } \\
2016 \text { (IPR Praha) }\end{array}$ & $\begin{array}{l}\text { v r. } 2015 \text { nový } \\
\text { kongresový sál, další } \\
\text { plány nejsou známy }\end{array}$ \\
\hline
\end{tabular}

Tab. 1. Přehledné srovnání zjištěných údajů o jednotlivých areálech 


\section{Zdroje a zpracování dat}

Výchozí data pro analýzu byla získána prostřednictvím webové služby Cadmapper, která shromažduje data ze zdrojů typu open source jako OpenStreetMap, NASA nebo USGS[3]. Následně umožňuje stažení souborů ve formátu DXF, který může být dál standardně zpracováván pomocí softwaru typu CAD. Menší soubory dat jsou k dispozici zdarma, větší datové sady je možné získat za poplatek nebo stahovat postupně po částech. Takto získaná prostorová data týkající se výstavních areálů byla převedena do formátu DWG v AutoCADu (verze 2016) a podložena rastrovými externími referencemi dvojího typu: aktuálními ortofotomapovými podklady z webu https://www.google.com a orientačními plánky jednotlivých výstavních areálů, staženými z webových stránek provozovatelů areálů nebo pořadatelů akcí. Smyslem využití ortofotomap je vizuální kontrola relevance získaných datových podkladů. Společně s online verzí map umožňují stanovit hranici zkoumaného území, tj. vymezit celkovou rozlohu výstavního areálu[4]. K vymezení výstavní části areálu pak slouží plánky pořádaných akcí, které rozlišují prostory a budovy určené návštěvníkům od provozního zázemí[5]. Následně je možné v rámci areálu stanovit plochy zastavěné budovami a přistoupit $\mathrm{k}$ analýze $\mathrm{a}$ interpretaci výsledků. $\mathrm{V}$ rámci průzkumu byla porovnávána míra využití, tj. poměr výstavní části areálu $\mathrm{k}$ jeho celkové rozloze, a míra zastavění, tj. poměr mezi budovami a volnými plochami.

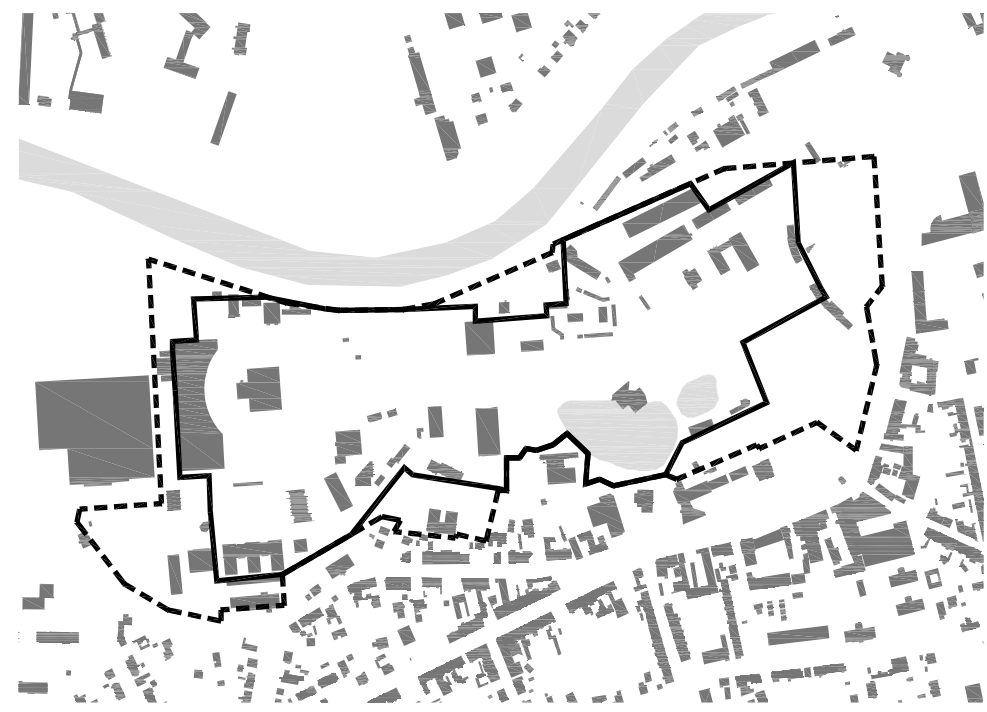

Obr. 1. Ukázka zpracovaných podkladů. V případě výstaviště v Českých Budějovicích tvoří na jedné straně dobře rozpoznatelnou hranici areálu řeka Vltava, která výstaviště odděluje od centra města. Na straně vzdálenější od města je patrný rozdíl mezi volnou pavilono- 
vou zástavbou výstavního areálu a strukturou městské zástavby s drobnějšími nájemními a rodinnými domy. Přerušovanou čarou je vyznačena celková plocha areálu, plnou čarou část areálu, ve které probíhají výstavy.

\section{Výsledky srovnání areálů}

Parametr 1: Významným parametrem, který lze na základě získaných dat porovnávat, je využitelnost areálu. Tou je míněn poměr celkové rozlohy areálu k velikosti jeho výstavní části, tj. části areálu určené pro konání akcí a pohyb návštěvníků.

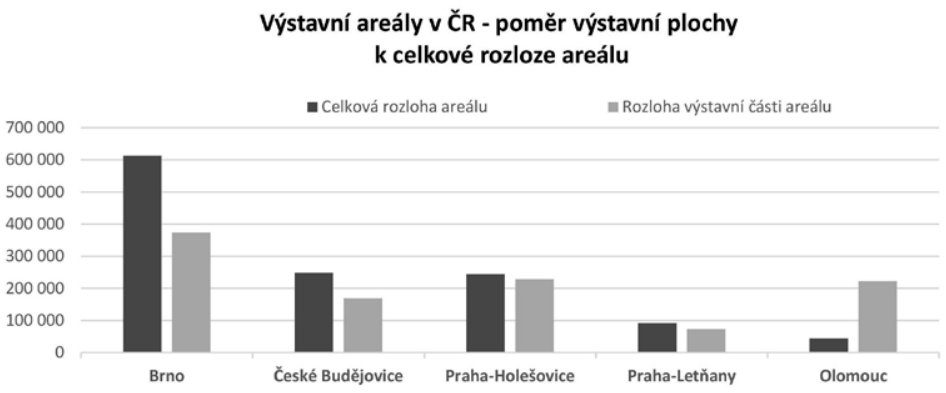

Tab. 2. Využitelnost: poměr velikosti výstavní plochy k celkové rozloze areálu. Z tabulky je zřejmá také celková velikost jednotlivých výstavišt' (seřazeno sestupně).

Největší celkovou rozlohu má brněnský areál, který také z historických důvodů disponuje nejrozsáhlejším technickým zázemím. V Brně se v minulosti (myšleno v období plánované ekonomiky v 50.-80. letech 20. století) konaly rozsáhlé celonárodní přehlídky průmyslu a také se zde centrálně realizovaly expozice určené pro oficiální zahraniční účasti, čemuž odpovídala technická infrastruktura. V současnosti maximální kapacitu areálu využívá pouze několik akcí ročně, z nichž nejvýznamnější je Mezinárodní strojírenský veletrh, pořádaný každoročně od roku 1959. Po zbytek roku se na výstavišti konají menší akce, často zde probíhá více akcí současně.

Příznivého poměru mezi velikostí výstavní části a celkovou rozlohou areálu dosahují obě pražská výstaviště. Tento rys mají oba areály společný, přestože podle jiných parametrů je jejich charakter velmi odlišný. Moderní komerční areál v PrazeLetňanech tvoří kompaktní halová zástavba s minimem volných prostranství, pouze s nezbytnými komunikačními koridory a parkovacími plochami. Výstaviště v PrazeHolešovicích je naopak ukázkou historické urbanistické kompozice se solitérními objekty volně rozmístěnými na parkově upravených prostranstvích. V tomto př́padě poměr mezi velikostí výstavní části a celkovou rozlohou výstaviště vypovídá o absenci kapacitních parkovacích ploch a minimálním rozsahu technického zázemí. 
Výstaviště České Budějovice se poměrem celkové rozlohy k velikosti výstavní části podobá brněnskému výstavišti. Zde je tento poměr daný částečně prrítomností a velikostí technického zázemí a částečně zahrnutím parkovacích kapacit do celkové rozlohy areálu.

Výjimečná je situace $\mathrm{v}$ př́padě Olomouce, kde na stálém výstavišti s menší rozlohou (oproti ostatním sledovaným areálům) probíhají během roku pouze regionální akce odpovídajícího rozsahu. Třikrát do roka se však při pořádání mezinárodní zahradnické výstavy[6] areál dočasně propojí s městskými sady a tím zvětší na několikanásobek své rozlohy. $V$ prrípadě olomouckého výstaviště je parkování pro návštěvníky řešeno převážně záchytnými parkovišti, která bezprostř̌edně nenavazují na vlastní prostor výstavy, jsou však v docházkové vzdálenosti. Při zohlednění jejich rozlohy by byl rozdíl mezi velikostí stálého výstaviště a prostorem potřebným pro uspořádání velké mezinárodní výstavy ještě výraznější.

Parametr 2: Dalším sledovaným parametrem, který vypovídá o charakteru výstavního areálu, je intenzita zástavby čili poměr mezi plochou zastavěnou výstavními pavilony a jinými budovami a volnými plochami.

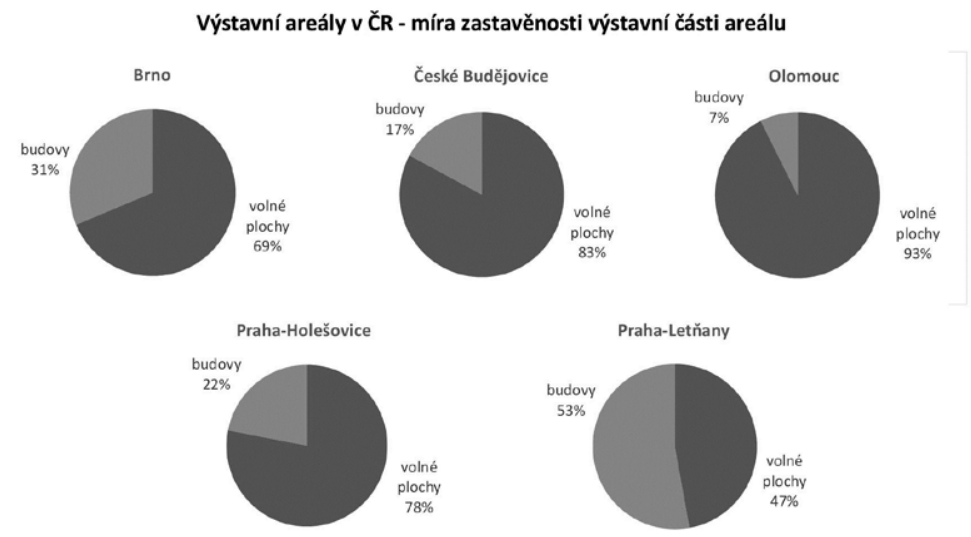

Tab. 3. Zastavěnost: srovnání poměrů volných ploch $\mathrm{k}$ ploše zastavěné budovami v jednotlivých areálech

Výstaviště v Českých Budějovicích, Praze-Holešovicích a Olomouci mají v zásadě obdobný prostorový charakter. Jedná se o rozsáhlé parkově upravené areály s volně rozmístěnými solitérními pavilony. To odpovídá i skladbě zde pořádaných akcí $\mathrm{s}$ důrazem na akce společenské a kulturní, případně sportovní. $\mathrm{V}$ prrípadě výstavišt v Olomouci a Českých Budějovicích tento charakter areálu koresponduje také s hlavní 
pořádanou akcí: zemědělské i zahradnické výstavy využívají ve značné míře expozice na volných plochách. V př́mém protikladu je areál v Praze-Letňanech provozovaný jako komerční areál, s čímž koresponduje vysoká míra zastavění budovami. Jde de facto o kobercovou halovou zástavbu, srovnatelnou se stavbami pro logistiku nebo výrobu. Mezi těmito dvěma krajními polohami se nachází brněnské výstaviště, kde se v rámci jednoho areálu organicky spojuje historická část s parkovými úpravami a moderní část $s$ halovou zástavbou.
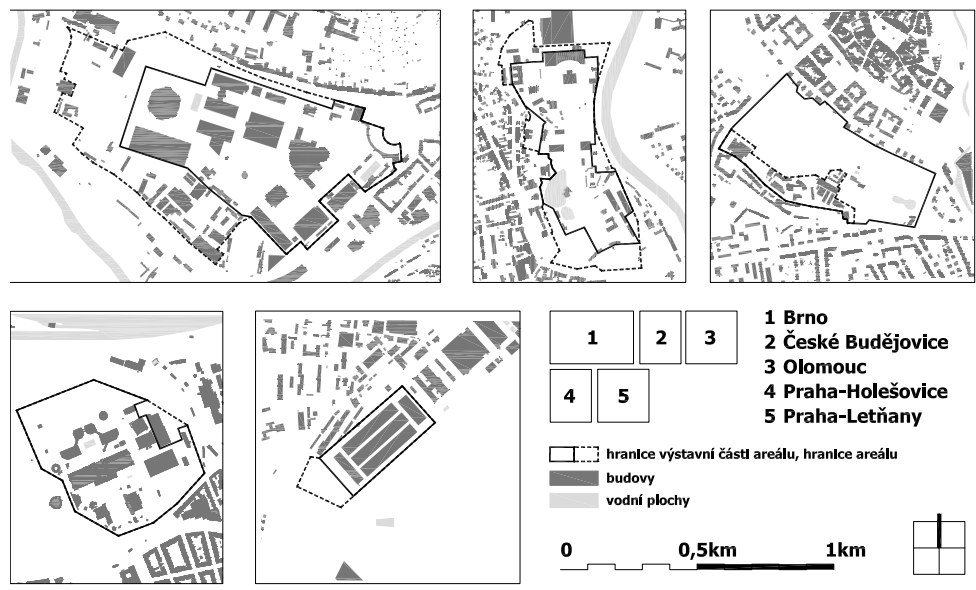

Obr. 2. Srovnání velikosti jednotlivých výstavních areálů a jejich vymezení v rámci struktury města. Dobře patrné jsou rozdíly v charakteru zástavby; zejména je patrná kompaktní halová zástavba areálu Praha-Letňany a rozsáhlé nezastavěné parkové plochy, které využívá pro výstavu Flora olomoucké výstaviště.

\section{Závěr}

Využitelnost výstavních areálů posuzovaná jako poměr mezi jejich celkovou rozlohou a velikostí plochy využitelné přímo pro výstavní akce se u sledovaných areálů výrazně liší. Roli zde hraje především to, zda má příslušný areál k dispozici rozsáhlejší provozní zázemí v podobě skladů výstavářského vybavení, dílen a podobně (Brno, České Budějovice, částečně Olomouc), nebo zda se zázemí omezuje pouze na nezbytné administrativní prostory (obě pražská výstaviště). Dále je podstatné, zda má výstavní areál na svých pozemcích vyčleněné parkovací plochy pro návštěvníky (Brno, České Budějovice, Praha-Letňany), nebo zda je dopravní obslužnost řešena především v synergii s městem mimo vlastní území výstaviště (Olomouc, Praha-Holešovice). Dopravní řešení přitom souvisí také s polohou areálu vůči centrální části města a napojením na hromadnou dopravu. Roli hraje i angažovanost státní správy a samosprávy v provozu výstaviště, která zejména $\mathrm{v}$ prŕṕpadě olomouckého výstaviště 
umožňuje veletržní správě využití veřejného prostoru v míře, která by u komerčních subjektů byla nemyslitelná.

Míra zastavěnosti výstavních areálů koresponduje především s typem pořádaných akcí. Na jedné straně škály jsou výstaviště zaměřená primárně na pořádání akcí na venkovních plochách, kde je zastavěnost nízká (Olomouc, České Budějovice). Na opačném pólu, pokud jde o zastavěnost, je areál v Praze-Letňanech, kde probíhají veletrhy a další akce celoročně a s ohledem na komerční charakter areálu je zde tlak na jeho maximální využití. Výstaviště v Brně a Praze-Holešovicích se této intenzitě využití s ohledem na historický vývoj a př́tomnost památkově chráněných budov zdaleka nepřibližují. U obou těchto areálů jsou navíc významnou součástí celku také parkově upravené venkovní prostory, které nabízejí možnost využití pro další typy akcí.

Ze zjištěných údajů dále vyplývá jednota právní formy a v kontrastu k tomu naprostá nejednoznačnost statusu výstavních areálů v územněplánovací dokumentaci. Jedná se zjevně o důsledek faktu, že výstaviště plní vždy více funkcí současně a je pouze na zpracovateli územního plánu, $\mathrm{k}$ jaké interpretaci významu veletržního areálu se přikloní.

\section{Poznámky}

[1] Význam veletržních areálů v České republice byl ověřován na základě statistik oborových institucí: UFI, SOVA ČR a CENTREX. Pro analýzu vlastnických vztahů a ÚPD byly využity následující webové stránky: vlastnické vztahy: https:// rejstrik-firem.kurzy.cz/, vlastnictví pozemků: https://nahlizenidokn.cuzk.cz/, ÚP Brno: https://gis.brno.cz/ags/upmb/, ÚP České Budějovice: http://www.cbudejovice.cz/uzemni-plan-mesta-ceske-budejovice, ÚP Olomouc: www.olomouc.eu/o-meste/uzemni-planovani/novy-uzemni-plan, ÚP Praha: https://plan. iprpraha.cz/cs/metropolitni-plan, a webové stránky jednotlivých veletržních správ (výroční zprávy a obecné informace)

[2] Některé výstavní areály mají oficiální název, jiné jsou známější pod názvem svého provozovatele. V kontextu místního pojmenování a značení se zpravidla používá pouze název výstaviště bez další specifikace, pražská výstaviště mají shodně $\mathrm{v}$ názvu Praha. $\mathrm{V}$ tomto textu jsou proto pro přehlednost jednotlivé areály označovány jednotně podle města, respektive místa. Oficiální názvy areálů a jejich provozovatelů jsou uvedeny v tabulce (Tab. 1).

[3] Informace o službě a podmínkách jejího využití a data ke stažení jsou dostupné na webové stránce https://cadmapper.com/. K dispozici je také více než 200 souborů ve formátu DXF s datovými podklady evropských i světových měst.

[4] Areály mají většinou v území zřetelně patrné hranice, které tvoří významné 


\section{$60 \quad$ PReS 2018 conference papers}

komunikace nebo uliční sít. V nejasných případech lze průběh hranice areálu zpřesnit s využitím údajů o vlastnictví pozemků a budov, které je možné získat díky službě Nahlížení do katastru nemovitostí. Aplikace je přístupná na stránce https://nahlizenidokn.cuzk.cz/.

[5] Charakteristickým znakem výstavních areálů je jejich variabilita; prostor pro výstavní akce je proto obtížné stanovit naprosto jednoznačně. Rozdíly mezi jednotlivými areály jsou však natolik výmluvné, že menší nepřesnosti ve vymezení ploch nejsou relevantní.

[6] Mezinárodní květinová a zahradnická výstava Flora Olomouc se koná v jarním, letním a podzimním termínu s celkovou roční návštěvností okolo 180 tisíc platících návštěvníků. Zdroj: výroční zpráva akciové společnosti Flora Olomouc, 2015. 